\title{
Commuter couples and careers Moving together for him and apart for her
}

\author{
Marta Murray-Close*
}

February 23, 2016

\begin{abstract}
Research on the migration patterns of couples has found that men's human capital has a larger impact than women's on family location choices, but an emerging qualitative literature shows that some couples avoid location-related tradeoffs between their careers by living apart. I propose a new method of identifying couples who live apart in the American Community Survey and use the method to construct the first nationally representative sample of matched noncohabiting husbands and wives. Consistent with previous research, I find that husbands' education has a larger impact than wives' on the probability that couples migrate together. In contrast, wives' education has a larger impact on the probability that couples live apart. I argue that family location choices are analogous to marital naming choices: husbands rarely accommodate wives, whatever their circumstances, but wives accommodate husbands unless the cost of accommodation is unusually high.
\end{abstract}

\section{Introduction}

In an era where most women, including most mothers, are in the labor force, heterosexual marriage is no longer defined by gender-based household specialization. But the rise of dual-earner households has been the end of gender-differentiated economic roles. Faced with the challenge of reconciling competing demands from two jobs or two careers, some couples treat wives as secondary earners, prioritizing the employment opportunities of husbands when conflicts arise. A large empirical literature shows that family migration patterns reflect this tendency: in deciding whether and where to migrate, couples appear to weight the education and employment opportunities of husbands more heavily than those of wives (Shihadeh, 1991; Nivalainen, 2004; Compton and Pollak, 2007; McKinnish, 2008). This paper examines an alternative to family

*mmurrayclose@gmail.com. This paper was prepared for the 2016 meeting of the Easter Economic Association. The research was conducted while the author was a member of the economics faculty at the University of Massachusetts Amherst. 
migration that has received almost no attention from quantitative researchers, marital noncohabitation, and asks whether the gender asymmetry observed in decisions about migration carries over into decisions about noncohabitation.

A small but growing qualitative literature shows that, when choosing a shared location would compromise the career of one or both partners, some dual-career couples opt instead of live apart. While living apart frees both men and women to pursue desirable career opportunities wherever they arise, interviews with noncohabitors show that many view wives as the primary beneficiaries of the arrangement (Gross, 1980; Gerstel and Gross, 1982; Rhodes, 2002). In addition, many noncohabitors reject traditional gender roles and express a commitment to career growth for women as well as men (Gross, 1980; Gerstel and Gross, 1982; van der Klis and Mulder, 2008; van der Klis and Karsten, 2009; Lindemann, 2014). While qualitative studies of noncohabitation offer rich insights about the motivations and experiences of some couples who live apart, their generalizability is limited by a reliance on nonrandom samples. We cannot determine from these studies whether couples who live apart differ from other dual-earner couples, so we do not know what characteristics of husbands and wives increase their probability of living apart.

Quantitative research on marital noncohabitation has been limited by a lack of data. Most datasets from large-scale surveys do not track marriages across household boundaries. On the one hand, surveys that sample families usually assume that married couples live together; these surveys may gather information about both spouses in commuter couples, but they do not identify the couples as commuters. On the other hand, surveys that sample households usually exclude family members who live elsewhere; these surveys may identify married men and women who live apart from their spouses, but they do not gather information about the absent spouses. Because researchers have not had access to large probability samples containing matched data on husbands and wives who live apart, it has not been possible to compare the impact of husbands' and wives' characteristics on the probability of noncohabitation. The only previous study of marital noncohabitation to present nationally representative estimates suffered from this problem, so the authors speculated but did not present evidence about the role of dual-earner location constraints in motivating noncohabitation (Rindfuss and Stephen, 1990).

This paper uses data from the American Community Survey (ACS) to conduct the first nationally representative analysis of matched husbands and wives in commuter couples. I use data on migration and marriage in the year before the survey to identify co-residential married couples who were married to each other and living apart one year ago. Because these couples currently share a household, the ACS data contain information about both the husband and the wife. I am therefore able to estimate the effect of the husband's education on the probability that a couple lived apart one year ago, conditional on the wife's education, and the effect of the wife's education, conditional on the husband's education. The results show that the effects of education in noncohabitation decision, like the effects in migration decisions, are asymmetric 
with respect to gender. The direction of the asymmetry, however, is reversed: whereas the husband's education is a stronger predictor of migration, the wife's education is a stronger predictor of noncohabitation.

\section{Data: A representative sample of noncohabitors}

This paper uses data from the 2008-10 three-year sample of the American Community Survey (ACS), a 3-in-100 national random sample of the United States population, obtained from the Integrated Public Use Microdata Series (IPUMS) (Ruggles et al., 2015). I use two subsamples in the analysis. The first subsample, which I refer to as the "worker sample" contains $3,755,247$ people age 25 to 59 who were employed in the last five years, most recently worked in a civilian occupation, and lived in the United States one year ago. The second subsample, which I refer to as the "couple

sample" contains 950,026 co-residential married couples with both spouses in the worker sample and married for at least one year. The ACS sample is a weighted sample. To obtain nationally representative estimates, I apply person- or householdlevel sample weights throughout the analysis.

\subsection{Measuring marital noncohabitation}

The most straightforward method of identifying noncohabitors in the ACS data uses marital status and the relationships between household members to locate men and women who are currently married and living in a household without their spouse. The ACS question about marital status offers "separated" as a response option, so respondents who consider themselves to be separated rather than married can be excluded. This method of identifying noncohabitors, which was introduced by Rindfuss and Stephen (1990), has the advantage of identifying all of the noncohabitors in the data, so samples produced with the method represent the population of noncohabitors, defined as inclusively as possible, at the time of the survey. On the other hand, the method has the significant disadvantage of identifying individual noncohabitors in isolation from their spouses. Because the ACS does not gather information about family members who are absent from the household, samples produced with the method cannot be used to test predictions about the relative impact of husbands' and wives' characteristics on family location choices.

An alternative method of identifying noncohabitors became possible in 2008, when the ACS began asking about the timing of marriages. This information, combined with information about family relationships and migration, allows me to identify currently co-residential husbands and wives who were married and living apart one year ago. Specifically, I use the relationships between household members to locate men and women who are currently married and living with their spouse. I then compare the location of each husband one year ago with the location of his wife to identify the subset of couples who lived in different locations one year ago. Finally, I 
use the timing of these couples' marriages to exclude those who were not yet married when they lived apart.

This alternative method of identifying noncohabitors is an advance over the previous method in that it produces a sample of matched noncohabiting husbands and wives. Unfortunately, the advance comes at a cost: because this method identifies only the subset of last year's noncohabitors who reunited during the year, it represents the population of reuniters and not the population of all noncohabitors. Compared with other noncohabitors, reuniters are more likely to have lived apart for short durations. Thus, to the extent that the behavior of short-term noncohabitors differs from that of long-term noncohabitors, parameters estimated on samples produced with this method will not generalize to the population of all noncohabitors.

When defining noncohabitors as husbands and wives who lived in different locations one year ago, it is necessary to specify the meaning of "location." The smallest geographic areas that can be identified in the public-use ACS data are Public Use Microdata Areas (PUMAs). A PUMA is a geographically contiguous area nested within a state, comprising a group of census tracts or counties, and containing at least 100,000 residents. Studies of family migration often focus on slightly larger geographic areas meant to approximate local labor markets: metropolitan areas for metropolitan residents and non-metropolitan PUMAs or counties for others (Compton and Pollak, 2007; McKinnish, 2008). A third possibility is to define noncohabitors as husbands and wives who lived in different states one year ago. The ideal definition of a location for my purposes would be one that captures noncohabitation due to dual-earner location conflicts and excludes noncohabitation for other reasons.

The ACS does not ask couples about the reasons for their location choices, so it is not possible to determine directly from the data which definition of a location best operationalizes the concept of commuter partnerships. Given, however, that highly educated workers are more likely than workers with less education to participate in national or international labor markets and to move for specific jobs, we would expect a definition that captures work-motivated location choices to show migration rates increasing with educational attainment. Table 1 shows the proportion of men and women in the worker sample who migrated in the last year, at several levels of education, for each definition of a location given above. The migration rate increases monotonically with education under all three definitions but increases most quickly under the most restrictive definition: the migration rate among men and women with doctoral degrees exceeds the rate among those with less than a bachelor's degree by a factor of 2.7 when migration is defined as moving between states but just 1.7 when it is defined as moving between metropolitan areas or non-metropolitan PUMAs and 1.6 when it is defined as moving between PUMAs. In light of these results, in the regression models below, I define noncohabitors as husbands and wives who lived in different states one year ago. 
Table 1: Proportion migrating in last year, by education and definition of migration

\begin{tabular}{|c|c|c|c|}
\hline \multirow[b]{2}{*}{ Highest degree } & \multicolumn{3}{|c|}{ Migration defined as moving to different. . } \\
\hline & PUMA & $\begin{array}{c}\text { Metro area or } \\
\text { non-metro PUMA }\end{array}$ & State \\
\hline Less than bachelor's & 0.048 & 0.039 & 0.019 \\
\hline Bachelor's & 0.058 & 0.046 & 0.028 \\
\hline Master's & 0.058 & 0.048 & 0.032 \\
\hline Professional & 0.065 & 0.054 & 0.038 \\
\hline Doctoral & 0.079 & 0.068 & 0.051 \\
\hline
\end{tabular}

Notes: Sample for first and third definitions is worker sample: people age 25 to 59 , employed in the last five years, most recently working in a civilian occupation, and living in the United States one year ago. Sample for second definition is worker sample, excluding people currently or previously living in a PUMA that crosses metropolitan boundaries.

\subsection{Prevalence of marital noncohabitation}

Because there have been no nationally representative studies of marital noncohabitation among highly educated workers, a baseline question in this paper is, how prevalent is noncohabitation in the general population, and does the prevalence vary with education? Column A of Table 2 shows the proportion of married men and women in the worker sample, at each level of education, who currently live in a household without their spouse. The estimates in this column indicate that, by the most inclusive definition, the prevalence of noncohabitation follows a U-shaped pattern with respect to education: the percentage of married men and women currently living in a household without their spouse is 5.3 among those with less than a bachelor's degree, declines to 2.5 percent among those with a master's degree, and then increases to 3.7 among those with a doctoral degree.

As noted above, a limitation of studying noncohabiting couples who reunite in a given year is that my sample captures only a subset of the couples who live apart at the beginning of the year. To assess the coverage of a sample of reuniters relative to the population of all noncohabitors, I compare the estimates of the current prevalence of noncohabitation, which I assume to be a reasonable proxy for the prevalence of noncohabitation one year ago, with estimates of the prevalence of reuniting. Column B of Table 2 shows the proportion of men and women in the couple sample, at each level of education, who reunited from different PUMAs in the last year. The ratios of the proportions in this column with the proportions in column A suggest that a sample of reuniters captures between 8 and 22 percent of noncohabitors, with coverage lowest at the lowest level of education and increasing monotonically with education. Given that the current noncohabitors represented in column A include couples who live in different households but not different PUMAs, these figures are lower-bound estimates of coverage. In addition, the apparent gradient of coverage with respect 
Table 2: Proportion living apart from spouse, by education and definition of living apart

\begin{tabular}{lccccc}
\hline & \multicolumn{3}{c}{ Definition of living apart } & & \\
\cline { 2 - 5 } & $\begin{array}{c}\text { A } \\
\text { Different } \\
\text { households } \\
\text { How }\end{array}$ & $\begin{array}{c}\text { B } \\
\text { Different }\end{array}$ & $\begin{array}{c}\text { PUMAs last } \\
\text { Different } \\
\text { states last }\end{array}$ & & \\
\hline Less than bachelor's & 0.0525 & 0.0040 & 0.0019 & 0.08 & 0.48 \\
Bachelor's & 0.0270 & 0.0035 & 0.0019 & 0.13 & 0.54 \\
Master's & 0.0246 & 0.0041 & 0.0023 & 0.17 & 0.56 \\
Professional & 0.0249 & 0.0047 & 0.0029 & 0.19 & 0.62 \\
Doctoral & 0.0371 & 0.0083 & 0.0059 & 0.22 & 0.71 \\
\hline
\end{tabular}

Notes: Sample for first definition is married men and women in worker sample, which is described in notes to Table 1. Sample for second and third definitions is men and women in couple sample: members of co-residential married couples with both spouses in worker sample and married for at least one year.

to education may reflect, in part, larger shares of same-PUMA noncohabitors and correspondingly larger understatements of coverage among the less educated.

Since I am interested in noncohabitation motivated by dual-earner location constraints, and given the evidence from migration patterns that a state-based definition of noncohabitation is more likely than more-inclusive definitions to identify the relevant subset of noncohabitors, it is also informative to compare the prevalence of noncohabitation under the state-based definition suggested above with the prevalence under the household- and PUMA-based definitions. Column $\mathrm{C}$ of Table 2 shows the proportion of men and women in the couple sample, at each level of education, who lived in a different state from their spouse one year ago. By this definition, in contrast with the household-based definition, the prevalence of noncohabitation increases monotonically with education. In addition, the ratios of the proportions in column $\mathrm{C}$ to the proportions in column B suggest that many noncohabitors live apart in relatively close proximity, especially at lower levels of education. Of men and women who lived in a different PUMA from their spouse one year ago, the percentage who lived in a different state ranges from 48 among those with less than a bachelor's degree to 71 among those with a doctoral degree.

\section{Descriptive statistics: Characteristics of noncohabitors}

Table 3 presents descriptive statistics for the couple sample. To provide a comparison between noncohabitors and other couples, the table presents average characteristics for the whole sample and for the subsample of couples who lived in different states one 
Table 3: Variable means

\begin{tabular}{|c|c|c|c|c|c|c|}
\hline \multirow[b]{2}{*}{ Variable } & \multicolumn{2}{|c|}{ Husband } & \multicolumn{2}{|c|}{ Wife } & \multicolumn{2}{|c|}{ Couple } \\
\hline & All & $\begin{array}{l}\text { Nonco- } \\
\text { habitors }\end{array}$ & All & $\begin{array}{l}\text { Nonco- } \\
\text { habitors }\end{array}$ & All & $\begin{array}{l}\text { Nonco- } \\
\text { habitors }\end{array}$ \\
\hline Less than bachelor's & 0.648 & 0.600 & 0.622 & 0.575 & & \\
\hline Bachelor's & 0.220 & 0.211 & 0.241 & 0.229 & & \\
\hline Master's & 0.086 & 0.108 & 0.104 & 0.118 & & \\
\hline Professional & 0.029 & 0.037 & 0.022 & 0.038 & & \\
\hline Doctoral & 0.018 & 0.044 & 0.011 & 0.040 & & \\
\hline Age & $\begin{array}{l}44.089 \\
(8.861)\end{array}$ & $\begin{array}{l}42.083 \\
(9.297)\end{array}$ & $\begin{array}{l}42.227 \\
(8.860)\end{array}$ & $\begin{array}{l}40.216 \\
(9.171)\end{array}$ & & \\
\hline White & 0.811 & 0.697 & 0.808 & 0.686 & & \\
\hline Non-Hispanic & 0.879 & 0.870 & 0.875 & 0.852 & & \\
\hline Children age $0-5$ & & & & & 0.271 & 0.261 \\
\hline Children age 6-12 & & & & & 0.325 & 0.263 \\
\hline Children age $13-17$ & & & & & 0.268 & 0.205 \\
\hline$N$ & 950,026 & 1,795 & 950,026 & 1,795 & 950,026 & 1,795 \\
\hline
\end{tabular}

Notes: Sample is couple sample, which is described in notes to Table 2. Noncohabitors are couples who lived in different states one year ago. Numbers in parentheses are standard deviations.

year ago. Consistent with Rindfuss and Stephen (1990), whose analysis of US Census data from 1960, 1970, and 1980 shows that living in a household without one's spouse is more common at younger ages, noncohabitors in the couple sample are about two years younger than average. Also consistent with Rindfuss and Stephen (1990), noncohabitors are less likely than average to be white. Corroborating qualitative evidence that children deter couples from living apart (Gerstel and Gross, 1982; van der Klis, 2008), couples who lived in different states one year ago are less likely than other couples to have children. Notably, however, more than a quarter of noncohabitors do have children.

Not surprisingly, given the evidence in Table 2 that noncohabitation is more common among the more educated, the variable means in Table 3 show that noncohabitors are more likely than average to have advanced degrees. This difference is very pronounced at the professional and doctoral levels, especially for women. A noncohabiting wife is nearly twice as likely as the average wife to have a professional degree and nearly four times as likely to have a doctoral degree. These results are, to my knowledge, the first nationally representative evidence - albeit indirect evidence that dual-career location problems motivate marital noncohabitation for a nontrivial number of highly educated workers. 


\section{Regression analylsis: Who moves together, and who moves apart?}

The regression analysis in this paper focuses on three main questions: First, does the probability that a married couple lives apart increase with the husband's and the wife's education? Second, does the impact of the husband's education differ from the impact of the wife's education? And finally, does the relative importance of the husband's and the wife's education in predicting marital noncohabitation differ from their relative importance in predicting migration? To answer these questions, I use the sample of couples who lived in different states one year ago to estimate the effect of the husband's education conditional on the wife's education and the effect of the wife's education conditional on the husband's education. Given the dearth of generalizable research on commuter couples and marital noncohabitation, I also estimate and discuss the effects of demographic characteristics on family location choices.

\subsection{Effect of husband's and wife's education on location choices}

To assess the impact of the husband's and the wife's education on the probability that a couple lives apart, controlling for demographic differences that may be correlated with education and location choices, I estimate a logit model,

$$
\log \left(P\left(E_{c}=1\right) / P\left(E_{c}=0\right)\right)=\beta_{0}+\boldsymbol{E} \boldsymbol{d}_{\boldsymbol{c}} \boldsymbol{\beta}_{\mathbf{1}}+\boldsymbol{X}_{\boldsymbol{c}} \boldsymbol{\beta}_{\mathbf{2}},
$$

where $c$ indexes couples and $E_{c}$ is an indicator for living in different states one year ago. $\boldsymbol{E} \boldsymbol{d}_{\boldsymbol{c}}$ is a vector containing the husband's and wife's highest degree (indicators for bachelor's, master's, professional, and doctoral degrees). $\boldsymbol{X}_{\boldsymbol{c}}$ is a vector of demographic control variables including the husband's and wife's age and age squared, the husband's and wife's race (indicators for white race), the husband's and wife's ethnicity (indicators for non-Hispanic ethnicity), the couple's parental status (indicators for living with children age 0 to 5 , ag e 6 to 12, and age 13 to 17), the husband's and wife's metropolitan status one year ago (indicators for living in a metropolitan area), and the husbands and wife's region of residence one year ago (indicators for eight of the nine Census regions).

To assess the impact of the husband's and the wife's education on the probability that a couple migrates, I also estimate model (1) where $E_{c}$ is an indicator for migrating in the last year. I consider a couple to have migrated if they moved together from one state to another. Because couples who lived in different states one year ago were not at risk of migrating by this definition I exclude noncohabitors from the estimation sample for the migration model.

Columns A-C of Table 4 report relative risk ratios from the migration model. Columns D-F report relative risk ratios from the noncohabitation model. With respect to the effects of demographic characteristics on family location choices, the estimates in Table 4 are largely consistent with the results of previous migration studies and 
with the descriptive statistics in Table 3. Younger couples are more likely than older couples to migrate, and there is some indication that they are more likely to live apart, although the latter effects are not statistically significant. White couples are less likely than couples of other races to live apart.

The most noteworthy demographic effects are the effects of children. Having children at home deters both migration and noncohabitation, but interestingly, older children deter migration more strongly than younger children, while younger children deter noncohabitation more strongly. These patterns suggest that older children add more than younger children to their families' costs of migrating, which is plausible given that children in elementary and especially high school stand to lose valuable social networks when their families move. In contrast, the patterns suggest that younger children add more than older children to their families' costs of living apart, perhaps because the extra burden of caretaking that falls to the parent who lives alone with the children is more onerous when the children are more dependent. Taken together, the estimated effects of children on family location choices suggest that couples view noncohabitation as a more feasible alternative to family migration at certain stages of the life course: before children arrive and after they gain some measure of self sufficiency.

Turning to the effects of primary interest, the estimates in columns A-C of Table 4 are consistent with the results of previous studies in showing that the husband's education has a larger impact than the wife's education on the probability that a couple migrates. Of particular note are the effects of advanced degrees. Relative to a husband without a bachelor's degree, a husband with a master's degree increases the risk of migrating relative to the risk of not migrating by a factor of 2.2. A husband with a professional degree increases the relative risk of migrating by a factor of 2.4 , and a husband with a doctoral degree increases it by a factor of 3.8. The comparable figures for wives are much lower, at $0.99,1.2$, and 1.4 .

The estimates from the noncohabitation model follow a strikingly different pattern. With the exception of the estimated effects of master's degrees, to which I will return, the estimates in columns D-F of Table 4 show that the wife's education has a larger impact than the husband's education on the probability that a couple lives apart. Relative to a wife without a bachelor's degree, a wife with a professional degree increases the risk of living apart relative to the risk of living together by a factor of 1.6, and a wife with a doctoral degree increases it by a factor of 2.6. The comparable figures for husbands are lower, at 1.2 and 2.0.

\subsection{Effect of occupation characteristics on location choices}

The estimates presented to this point suggest that couples weigh husbands' and wives' education differently in decisions about migration and noncohabitation. These results may reflect gender-asymmetric treatment of similarly situated husbands and wives, but they may also reflect gender differences in human capital and labor-market po- 
Table 4: Predictors of migration and noncohabitation, baseline model

\begin{tabular}{|c|c|c|c|c|c|c|}
\hline \multirow[b]{2}{*}{ Variable } & \multicolumn{3}{|c|}{ Migration } & \multicolumn{3}{|c|}{ Noncohabitation } \\
\hline & $\begin{array}{c}\text { A } \\
\text { Husband }\end{array}$ & $\begin{array}{c}\text { B } \\
\text { Wife }\end{array}$ & $\begin{array}{c}\text { C } \\
\text { Couple }\end{array}$ & $\begin{array}{c}\text { D } \\
\text { Husband }\end{array}$ & $\begin{array}{c}\text { E } \\
\text { Wife }\end{array}$ & $\begin{array}{c}\mathrm{F} \\
\text { Couple }\end{array}$ \\
\hline \multirow[t]{2}{*}{ Bachelor's } & $1.505^{*}$ & 1.029 & & 0.993 & 1.014 & \\
\hline & $(0.038)$ & $(0.026)$ & & $(0.066)$ & $(0.065)$ & \\
\hline \multirow[t]{2}{*}{ Master's } & $2.155^{*}$ & 0.993 & & $1.303^{*}$ & 1.128 & \\
\hline & $(0.069)$ & $(0.032)$ & & $(0.111)$ & $(0.094)$ & \\
\hline \multirow[t]{2}{*}{ Professional } & $2.441^{*}$ & $1.164^{*}$ & & 1.201 & $1.575^{*}$ & \\
\hline & $(0.115)$ & $(0.063)$ & & $(0.165)$ & $(0.214)$ & \\
\hline \multirow[t]{2}{*}{ Doctoral } & $3.835^{*}$ & $1.384^{*}$ & & $1.957^{*}$ & $2.578^{*}$ & \\
\hline & $(0.192)$ & $(0.090)$ & & $(0.255)$ & $(0.363)$ & \\
\hline \multirow[t]{2}{*}{ Age } & $0.931^{*}$ & $0.922^{*}$ & & 0.971 & 0.970 & \\
\hline & $(0.014)$ & $(0.014)$ & & $(0.036)$ & $(0.036)$ & \\
\hline \multirow[t]{2}{*}{ Age squared } & $1.000^{*}$ & $1.001^{*}$ & & 1.000 & 1.000 & \\
\hline & $(0.000)$ & $(0.000)$ & & $(0.000)$ & $(0.000)$ & \\
\hline \multirow[t]{2}{*}{ White } & 1.004 & 0.944 & & $0.675^{*}$ & $0.684^{*}$ & \\
\hline & $(0.041)$ & $(0.038)$ & & $(0.062)$ & $(0.063)$ & \\
\hline \multirow[t]{2}{*}{ Non-Hispanic } & 1.095 & $1.186^{*}$ & & 1.034 & 0.887 & \\
\hline & $(0.052)$ & $(0.056)$ & & $(0.117)$ & $(0.097)$ & \\
\hline \multirow[t]{2}{*}{ Children age $0-5$} & & & $0.921^{*}$ & & & $0.618^{*}$ \\
\hline & & & $(0.021)$ & & & $(0.038)$ \\
\hline \multirow[t]{2}{*}{ Children age $6-12$} & & & $0.817^{*}$ & & & $0.680^{*}$ \\
\hline & & & $(0.018)$ & & & $(0.040)$ \\
\hline \multirow[t]{2}{*}{ Children age $13-17$} & & & $0.713^{*}$ & & & $0.788^{*}$ \\
\hline & & & $(0.020)$ & & & $(0.049)$ \\
\hline
\end{tabular}

Notes: Columns A-C present relative risk ratios from a single logistic regression of one-year migration status on variables in table and couple's metropolitan status and region of residence one year ago. Columns D-F present relative risk ratios from a single logistic regression of noncohabitation status one year ago on same variables, allowing husband's and wife's metropolitan status and region of residence one year ago to differ. Numbers in parentheses are standard errors. Estimate is statistically different from $1,{ }^{*} p<0.05$. Sample is couple sample, which is described in notes to Table 2. 
sition. Gender segregation in occupations remains extensive in the United States, so men and women with the same level of education may face very different incentives for job-related migration. To determine whether the gender-asymmetric effects of education on family location choices persist when controlling for gender differences in occupation-related constraints, I estimate a logit model,

$$
\log \left(P\left(E_{c}=1\right) / P\left(E_{c}=0\right)\right)=\beta_{0}+\boldsymbol{E} \boldsymbol{d}_{\boldsymbol{c}} \boldsymbol{\beta}_{\mathbf{1}}+\boldsymbol{X}_{\boldsymbol{c}} \boldsymbol{\beta}_{\mathbf{2}}+\boldsymbol{O c c}_{\boldsymbol{c}} \boldsymbol{\beta}_{\mathbf{3}}
$$

that augments model (1) with a vector, $\boldsymbol{O} \boldsymbol{c c}_{\boldsymbol{c}}$, containing two occupation characteristics.

Occupations organized around national or international labor markets, where geographic flexibility is often a requirement for advancement, engender stronger incentives for workers to prioritize employment opportunities in their location choices than occupations with thick local labor markets. To capture variation across occupations in the extent to which workers participate in national versus local labor markets, I use the worker sample to estimate the percentage of prime-age, US-born workers in each ACS occupation category who live outside their birth state. Nearly two-thirds of workers in the worker sample live in their birth state, suggesting a strong preference for remaining near established social networks. Occupations with a majority of workers living outside their birth state are highly specialized; examples include scientists, pilots, doctors, postsecondary teachers, writers, actors, journalists, archivists, and clergy. On average, both men and women in the couple sample are in occupations with 38 percent of workers living outside their birth state.

Occupations may also shape location choices through their impact on earning potential. The human-capital model of family location choice predicts that couples will prioritize the employment opportunities of men over those of women because men earn more than women, on average (Sandell, 1977; Mincer, 1978). Under the assumption that couples maximize their joint income, it is rational for them to accept economic losses to one spouse - usually the wife - if the gains to the other spouse are large enough to offset them. To capture differences in earning potential across occupations, I use the worker sample to estimate the mean wage of workers in each ACS occupation category. On average, men in the couple sample are in occupations with a mean wage of $\$ 26.33$, and women are in occupations with a mean wage of $\$ 22.96$.

Table 5 reports relative risk ratios from model (2). Columns A and B report estimates from the migration model; columns $\mathrm{C}$ and $\mathrm{D}$ report estimates from the noncohabitation model. Controlling for differences in occupation characteristics does not alter the relative importance of the husband's and wife's education in family location choices. While the magnitudes of the education effects in both models are reduced by the addition of the occupation variables, the effects of the husband's education remain larger than the effects of the wife's education in the migration model, and the effects of the wife's education remain - again with the exception of master's degrees - larger than the estimated effects of the husband's education in the 
Table 5: Predictors of migration and noncohabitation, baseline model plus occupation characteristics

\begin{tabular}{|c|c|c|c|c|}
\hline \multirow[b]{2}{*}{ Variable } & \multicolumn{2}{|c|}{ Migration } & \multicolumn{2}{|c|}{ Noncohabitation } \\
\hline & $\begin{array}{c}\text { A } \\
\text { Husband }\end{array}$ & $\begin{array}{c}\text { B } \\
\text { Wife }\end{array}$ & $\begin{array}{c}\text { D } \\
\text { Husband }\end{array}$ & $\begin{array}{c}\mathrm{E} \\
\text { Wife }\end{array}$ \\
\hline Bachelor's & $\begin{array}{r}1.267^{*} \\
(0.034)\end{array}$ & $\begin{array}{c}0.989 \\
(0.025)\end{array}$ & $\begin{array}{c}0.934 \\
(0.066)\end{array}$ & $\begin{array}{c}0.979 \\
(0.065)\end{array}$ \\
\hline Master's & $\begin{array}{r}1.678^{*} \\
(0.058)\end{array}$ & $\begin{array}{r}0.920^{*} \\
(0.031)\end{array}$ & $\begin{array}{c}1.172 \\
(0.106)\end{array}$ & $\begin{array}{c}1.052 \\
(0.091)\end{array}$ \\
\hline Professional & $\begin{array}{r}1.923^{*} \\
(0.105)\end{array}$ & $\begin{array}{r}1.224^{*} \\
(0.074)\end{array}$ & $\begin{array}{c}1.207 \\
(0.187)\end{array}$ & $\begin{array}{r}1.551^{*} \\
(0.236)\end{array}$ \\
\hline Doctoral & $\begin{array}{r}2.305^{*} \\
(0.127)\end{array}$ & $\begin{array}{c}1.109 \\
(0.077)\end{array}$ & $\begin{array}{r}1.522^{*} \\
(0.218)\end{array}$ & $\begin{array}{r}2.089^{*} \\
(0.319)\end{array}$ \\
\hline $\begin{array}{l}\text { Percentage in occupation not in } \\
\text { birth state }\end{array}$ & $\begin{array}{r}1.032^{*} \\
(0.002)\end{array}$ & $\begin{array}{r}1.021^{*} \\
(0.002)\end{array}$ & $\begin{array}{r}1.018^{*} \\
(0.004)\end{array}$ & $\begin{array}{r}1.020^{*} \\
(0.005)\end{array}$ \\
\hline Mean wage in occupation & $\begin{array}{r}0.992^{*} \\
(0.001)\end{array}$ & $\begin{array}{r}0.987^{*} \\
(0.001)\end{array}$ & $\begin{array}{c}0.990^{*} \\
(0.003)\end{array}$ & $\begin{array}{c}0.991^{*} \\
(0.003)\end{array}$ \\
\hline
\end{tabular}

Notes: Columns A-B present relative risk ratios from a single logistic regression of one-year migration status on variables in table, demographic variables in Table 4, and couple's metropolitan status and region of residence one year ago. Columns C-D present relative risk ratios from a single logistic regression of noncohabitation status one year ago on same variables, allowing husband's and wife's metropolitan status and region of residence one year ago to differ. Numbers in parentheses are standard errors. Estimate is statistically different from $1,{ }^{*} p<0.05$. Sample is couple sample, which is described in notes to Table 2 .

noncohabitation model.

That the estimated effects of master's degrees follow different pattern than the effects of professional and doctoral degrees may reflect the disproportionate concentration of wives with mater's degrees in teaching, a profession that offers considerable geographic flexibility. Among wives with master's degrees, 32 percent are teachers; among husbands with master's degrees, just 12 percent are teachers. The occupations of husbands and wives with professional and doctoral degrees are much more similar. The most common occupations among both husbands and wives with professional degrees are judicial workers, including lawyers, and doctors, which account for 56 percent of husbands and 44 percent of wives with professional degrees. The most common occupations among both husbands and wives with doctoral degrees are postsecondary teachers and doctors, which account for 31 percent of husbands and 33 percent of wives with doctoral degrees. Table 6 reports relative risk ratios from estimating model (2) on the couple sample, excluding couples in which either the husband or wife is a teacher. In this restricted sample, the effect of a husband's and wife's master's degree are roughly equal. 
Table 6: Predictors of migration and noncohabitation, excluding teachers

\begin{tabular}{|c|c|c|c|c|}
\hline \multirow[b]{2}{*}{ Variable } & \multicolumn{2}{|c|}{ Migration } & \multicolumn{2}{|c|}{ Noncohabitation } \\
\hline & $\begin{array}{c}\text { A } \\
\text { Husband }\end{array}$ & $\begin{array}{c}\text { B } \\
\text { Wife }\end{array}$ & $\begin{array}{c}\text { D } \\
\text { Husband }\end{array}$ & $\begin{array}{c}\text { E } \\
\text { Wife }\end{array}$ \\
\hline Bachelor's & $\begin{array}{c}1.313^{*} \\
(0.038)\end{array}$ & $\begin{array}{c}1.035 \\
(0.029)\end{array}$ & $\begin{array}{c}0.986 \\
(0.074)\end{array}$ & $\begin{array}{c}1.012 \\
(0.073)\end{array}$ \\
\hline Master's & $\begin{array}{r}1.742^{*} \\
(0.066)\end{array}$ & $\begin{array}{c}1.076 \\
(0.041)\end{array}$ & $\begin{array}{c}1.293^{*} \\
(0.127)\end{array}$ & $\begin{array}{r}1.269^{*} \\
(0.122)\end{array}$ \\
\hline Professional & $\begin{array}{c}1.948^{*} \\
(0.115)\end{array}$ & $\begin{array}{c}1.349^{*} \\
(0.087)\end{array}$ & $\begin{array}{c}1.210 \\
(0.200)\end{array}$ & $\begin{array}{r}1.849^{*} \\
(0.291)\end{array}$ \\
\hline Doctoral & $\begin{array}{c}2.284^{*} \\
(0.135)\end{array}$ & $\begin{array}{c}1.224^{*} \\
(0.089)\end{array}$ & $\begin{array}{c}1.660^{*} \\
(0.248)\end{array}$ & $\begin{array}{r}2.229^{*} \\
(0.354)\end{array}$ \\
\hline
\end{tabular}

Notes: Columns A-B present relative risk ratios from a single logistic regression of one-year migration status on variables in table, demographic variables in Table 4, and couple's metropolitan status and region of residence one year ago. Columns C-D present relative risk ratios from a single logistic regression of noncohabitation status one year ago on same variables, allowing husband's and wife's metropolitan status and region of residence one year ago to differ. Numbers in parentheses are standard errors. Estimate is statistically different from $1,{ }^{*} p<0.05$. Sample is couple sample, as described in notes to Table 2, excluding teachers.

\section{Conclusions: Moving together for him and apart for her}

What might explain the larger impact of wives' professional and doctoral degrees on the probability that couples live apart? One possibility is that marital noncohabitation is a response of relatively gender-egalitarian couples to gender asymmetry in the cultural expectations of spouses. More specifically, marital noncoahbitation may be analogous to marital name change: wives accommodate husbands by default, and husbands rarelybut wives who find accommodation very costly may opt out. Research on marital change has found that women with more education, and especially women with advanced degrees, are more likely than women with less eduction to keep their names at marriage. This pattern may reflect the higher cost of the traditional practice to women with strong professional commitments. In contrast, husbands almost always keep their names, whatever their level of education and professional commitment (Goldin and Shim, 2004).

The results in this paper, while suggestive of gender asymmetry in decisions about noncohabitation, are limited in their generalizability by a lack of data on current marital noncohabitors. If noncohabiting couples who reunite in a given year differ in important ways from other noncohabiting couples, then estimates based on a sample of reuniters will represent only the population of reuniters and not the population of all noncohabitors. Augmenting individual- and family-based surveys with questions about the living arrangements of couples, and augmenting household-based surveys 
with questions about absent family members, would allow for an analysis of all noncohabitors in the cross section.

Taking a broader perspective, this paper highlights a non-traditional family arrangement in keeping with widespread changes in the relationship between families and labor markets. The past half century has witnessed a historic increase in women's labor force participation and a concomitant increase in the proportion of families who diverge from the traditional, gendered breadwinner-caretaker model. Among these non-traditional families are a growing number that extend across multiple households for reasons such as divorce, non-marital childbearing, incarceration, transnational migration, and the voluntary maintenance by couples of separate households in a single location (?). Marital non-cohabitation, like these other arrangements, challenges longstanding assumptions about what it means to be a family and points to a growing need for social and demographic researchers to document cross-household kinship ties. 


\section{References}

Compton, J. and Pollak, R. A. (2007). Why are power couples increasingly concentrated in large metropolitan areas. Journal of Labor Economics, 25(3):475-512.

Gerstel, N. and Gross, H. E. (1982). Commuter marriages: A review. Marriage and Family Review, 5(2):71-93.

Goldin, C. and Shim, M. (2004). Making a nname: Women's surnames at marriage and beyond. The Journal of Economic Perspectives, 18(2):143-160.

Gross, H. E. (1980). Dual-career couples who live apart: Two types. Journal of Marriage and the Family, 42(3):567-576.

Lindemann, D. J. (2014). "the decision was really made for us": Career and agency among spouses who live apart for work. Unpublished manuscript.

McKinnish, T. (2008). Spousal mobility and earnings. Demography, 45(4):829-849.

Mincer, J. (1978). Family migration decisions. Journal of Political Economy, $86(5): 749-773$.

Nivalainen, S. (2004). Determinants of family migration: Short moves vs. long moves. Journal of Population Economics, 17(1):157-175.

Rhodes, A. R. (2002). Long-distance relationships in dual-career commuter couples: A review of counseling issues. The Family Journal, 10(4):398-404.

Rindfuss, R. R. and Stephen, E. H. (1990). Marital noncohabitation: Separation does not make the heart grow fonder. Journal of Marriage and the Family, 52(1):259270 .

Ruggles, S., Genadek, K., Goeken, R., Grover, J., and Sobek, M. (2015). Integrated public use microdata series: Version 6.0 [machine-readable database].

Sandell, S. H. (1977). Women and the economics of family migration. Review of Economics and Statistics, 59(4):406-414.

Shihadeh, E. S. (1991). The prevalence of husband-centered migration: Employment consequences for married mothers. Journal of Marriage and Family, 53(2):432-444.

van der Klis, M. (2008). Continuity and change in commuter partnerships: Avoiding or postponing family migration. GeoJournal, 71(4):233-247.

van der Klis, M. and Karsten, L. (2009). The commuter family as a geographical adaptive strategy for the work-family balance. Community, Work and Family, $12(3): 339-354$. 
van der Klis, M. and Mulder, C. H. (2008). Beyond the trailing spouse: The commuter partnership as an alternative to family migration. Journal of Housing and the Built Environment, 23(1):1-19. 